Article

\title{
Effects of Medium Supplements on Somatic Embryo Maturation and DNA Methylation in Pseudotsuga gaussenii Flous, a Species under Protection
}

\author{
Ying Gao ${ }^{1}$, Xiaoyi Chen ${ }^{1}$, Ying Cui ${ }^{1}$, Huanhuan Zhao ${ }^{1}$, Ruirui Zhao ${ }^{1}$, Chengbi Liu ${ }^{1}$, Jian Zhao ${ }^{1}$, \\ Jinfeng Zhang ${ }^{1, *}$ and Lisheng Kong ${ }^{1,2, *}$
}

1 National Engineering Laboratory for Tree Breeding, Key Laboratory of Genetics and Breeding in Forest Trees and Ornamental Plants, Ministry of Education, The Tree and Ornamental Plant Breeding and Biotechnology Laboratory of National Forestry and Grassland Administration, College of Biological Sciences and Biotechnology, Beijing Forestry University, Beijing 100083, China; gying@zju.edu.cn (Y.G.); cxy919@bjfu.edu.cn (X.C.); cwfpyl@126.com (Y.C.); zhh1119@bjfu.edu.cn (H.Z.); zhaorui1012@gmail.com (R.Z.); lcb520@bjfu.edu.cn (C.L.); zhaojian0703@bjfu.edu.cn (J.Z.)

2 Centre for Forest Biology, Department of Biology, University of Victoria, Victoria, BC V8W 3N5, Canada

* Correspondence: zjf@bjfu.edu.cn (J.Z.); lkong@uvic.ca (L.K.)

check for updates

Citation: Gao, Y.; Chen, X.; Cui, Y.; Zhao, H.; Zhao, R.; Liu, C.; Zhao, J.; Zhang, J.; Kong, L. Effects of Medium Supplements on Somatic Embryo Maturation and DNA Methylation in Pseudotsuga gaussenii Flous, a Species under Protection. Forests 2022, 13, 288. https://doi.org/10.3390/f13020288

Received: 19 November 2021

Accepted: 5 February 2022

Published: 11 February 2022

Publisher's Note: MDPI stays neutral with regard to jurisdictional claims in published maps and institutional affiliations.

Copyright: (c) 2022 by the authors. Licensee MDPI, Basel, Switzerland. This article is an open access article distributed under the terms and conditions of the Creative Commons Attribution (CC BY) license (https:// creativecommons.org/licenses/by/ $4.0 /)$.

\begin{abstract}
Pseudotsuga gaussenii is a forest species under protection in China. Propagation via somatic embryogenesis is efficient and needed for recovering this species. In this research, effects of medium supplements, i.e., methylglyoxal-bis (guanylhydrazone) (MGBG), polyethylene glycol (PEG), and maltose, on somatic embryo (SE) development were studied. More mature SEs developed with the pre-maturation treatment medium supplemented with $50 \mu \mathrm{M}$ or $100 \mu \mathrm{M}$ MGBG. During SE maturation, when the medium was supplemented with both PEG and maltose, the over-proliferation of embryogenic tissue was suppressed. When maltose was eliminated from the maturation medium, SEs were slightly smaller but developed better than other treatments due to the supply of lower carbon source, whereas when PEG was taken out from the maturation medium, no mature SE was obtained, only the heavily-proliferated plant tissue. Meanwhile, DNA methylation levels differed in these SE maturation cultures at the late culture stage of SE maturation. The level increased sharply with no maltose treatment (20.28\%) while decreasing without PEG supplement (10.35\%). DNA methyltransferase genes MET1-1, MET1-2, MET1-3, CMT3, DRM1, and DRM2 were partially cloned in this study to detect their expression level via qPCR. Expression of these genes, except MET1-3, in the culture of no PEG was higher significantly than the cultures of other treatments at weeks 1 , 3 , and 10. Our results suggested that MGBG and/or PEG play an important role in stimulating SE development and maturation. Furthermore, sugar supplements at a lower level benefited SE maturation in Pseudotsuga gaussenii.
\end{abstract}

Keywords: MGBG; PEG; maltose; embryogenic tissues; proliferation; maturation; DNA methyltransferase; conifer

\section{Introduction}

Pseudotsuga gaussenii has been listed as an endangered species, under national protection of the secondary level in China, due to the long-term utilization and the extremely low reproductive rate as well as the difficulties in cutting propagation. Somatic embryogenesis (SEis) is a process in which somatic cells form new individuals without the fusion of gametes, similar to the developmental process of zygotic embryos [1]. Somatic embryogenesis (SEis) is an efficient method for clonal propagation and breeding in reforestation. Therefore, an optimized SEis technology is urgently needed for the large-scale propagation of endangered species, while SEis has not been reported in Pseudotsuga gaussenii.

Multiple factors may affect the development and maturation of somatic embryos (SEs) in higher plants. In addition to plant growth regulators, culture medium supplements, 
such as methylglyoxal-bis (guanylhydrazone) (MGBG), polyethylene glycol (PEG) 4000, and maltose are among these factors in conifers [2-4]. MGBG could inhibit the proliferation of embryogenic tissues via negatively regulating S-adenosyl-methionine decarboxylase (SAMDC), which is the key enzyme during polyamine biosynthesis [5]. In conifers, the strong inhibition of tissue proliferation by MGBG was observed [6]. MGBG could reduce the number of total SEs [7]. PEG 4000 is used as a non-plasmolyzing osmoticum of culture media and is unable to penetrate the cell membrane. The functions of PEG 4000 in promoting SE development and maturation, improving desiccation tolerance of SEs have been reported in various coniferous species, such as loblolly pine [8], white spruce [9], and maritime pine [10]. Maltose, as one kind of carbohydrate, could provide energy, as a carbon source, and osmotic effects during SE development in conifers [10,11]. However, the influence of MGBG/PEG/maltose on SE development was not confirmed in Pseudotsuga gaussenii.

DNA methylation is a common phenomenon of gene modification in organisms without a change of DNA sequence [12]. Generally, DNA methylation can be divided into the maintenance of methylation and de novo methylation [13]. The former refers to the process in which the original site of methylation remains unchanged after DNA replication. The latter does not depend on DNA replication, it happens in the locus, which has never been methylated, resulting in the formation of new methylation. According to the base sites of methylation, it can be divided into three types: $\mathrm{CG}, \mathrm{CHG}$, and $\mathrm{CHH}$ (H refers to A, C, or T). In plants, the maintenance of CG methylation depends on methyltransferase 1 (MET1). Chromatin methylase 3 (CMT3) is responsible for maintaining cytosine methylation in CHG nucleotide sequences. DRM2 and CMT2 catalyze the maintenance of asymmetric $\mathrm{CHH}$ methylation sites via de novo methylation. The de novo cytosine methylation in CG, CHG, and CHH nucleotide sequences depends on domains rearranged methylase 2 (DRM2) [14-16].

Many studies have reported that DNA cytosine methylation is involved in a variety of cellular activities in higher plants. These include the expression of different genes [17,18], the formation of heterochromatin [19], the regular replication of chromosome [20], X chromosome inactivation [21], and genomic imprinting [22]. More importantly, DNA methylation also plays an important role in SE development. Different SE developmental stages are companied by different DNA methylation levels in plants, such as Bactris gasipaes Kunth, Brassica, and rice [23-25].

The maturation medium used in this study for Pseudotsuga gaussenii was based on that used for Douglas-fir with some modifications [26], as Pseudotsuga gaussenii is a species close to Douglas-fir. Furthermore, MGBG/PEG/maltose treatments were tested to explore their effects on SE development and to establish a proper SEis system to stimulate SE maturation in Pseudotsuga gaussenii. In addition to SE development, DNA methylation was studied with PEG/maltose treatment. Furthermore, DNA methyltransferases (DNMTs) were cloned, and the expression levels of DNMTs were detected by qRT-PCR in this study.

\section{Materials and Methods}

\subsection{The Culture Process of SE Development}

Embryogenic tissue was induced from immature zygotic embryos of Pseudotsuga gaussenii with the induction media that was a half-strength modified Litvay's medium $(1 / 2 \mathrm{mLV})[27,28]$ supplemented with $2 \mathrm{mg} / \mathrm{L} 2,4$-dichlorophenoxyacetic acid (2,4-D), $1 \mathrm{mg} / \mathrm{L}$ 6-benzylamino adenine (6-BA), $0.8 \mathrm{~g} / \mathrm{L}$ hydrolyzed casein, $0.5 \mathrm{~g} / \mathrm{L}$ glutamine, $10 \mathrm{~g} / \mathrm{L}$ sucrose, $3 \mathrm{~g} / \mathrm{L}$ gellan gum. An elite embryogenic cell line YDF3-1 was then selected and used in this study. The embryogenic tissue was maintained and bulked up on the maintenance media that was a half-strength modified Litvay's medium $(1 / 2 \mathrm{mLV})[27,28]$ supplemented with $1 \mathrm{mg} / \mathrm{L}$ 2,4-D, $0.5 \mathrm{mg} / \mathrm{L}$ 6-BA, $0.5 \mathrm{~g} / \mathrm{L}$ hydrolyzed casein, $0.5 \mathrm{~g} / \mathrm{L}$ glutamine, $10 \mathrm{~g} / \mathrm{L}$ sucrose, and $3 \mathrm{~g} / \mathrm{L}$ gellan gum for maintenance. The culture was sub-cultured once at 2 weeks. Thereafter, $0.8 \mathrm{~g}$ embryogenic tissue was transferred to $50 \mathrm{~mL}$ liquid maintenance medium without gellan gum to start suspension culture in flasks. 
The flasks were placed on a shaker at $100 \mathrm{rpm}$. The suspended cells or tissue was then moved to liquid pre-maturation medium, i.e., $1 / 2 \mathrm{mLV}$ medium supplemented with $40 \mu \mathrm{M}$ $\mathrm{ABA}, 30 \mathrm{~g} / \mathrm{L}$ maltose, $0.4 \mathrm{~g} / \mathrm{L}$ hydrolyzed casein, $0.5 \mathrm{~g} / \mathrm{L}$ glutamine, and $50 \mathrm{~g} / \mathrm{L}$ PEG 4000 , for 2 weeks to promote embryo development at the early developmental stage. In order to stimulate SE maturation, the treated embryogenic tissue was transferred onto semi-solid SE mature medium, i.e., 1/2 mLV medium supplemented with $60 \mu \mathrm{M} \mathrm{ABA}$, $0.2 \mathrm{~g} / \mathrm{L}$ hydrolyzed casein, $0.4 \mathrm{~g} / \mathrm{L}$ glutamine, $30 \mathrm{~g} / \mathrm{L}$ sucrose, $10 \mathrm{~g} / \mathrm{L}$ maltose, $80 \mathrm{~g} / \mathrm{L}$ PEG 4000, and $6 \mathrm{~g} / \mathrm{L}$ gellan gum. SE maturation culture was kept for 8 weeks before data collection. All culture media in this research were adjusted to $\mathrm{pH} 5.8$ before autoclave, and the cultures were kept in darkness, $23 \pm 1{ }^{\circ} \mathrm{C}$.

\section{2. $M G B G / P E G / M a l t o s e$ Treatments}

MGBG was firstly dissolved into $50 \mathrm{mM}$ solution by distilled water and then filtersterilized. During the pre-maturation treatment stage, MGBG was added into a prematuration medium to make the concentrations of $0,50,100$, or $200 \mu \mathrm{M}$ and used in the second week of pre-maturation. Then, $0.2 \mathrm{~g}$ embryogenic tissues were transferred to each petri dish containing maturation medium, and the number of mature, abnormal, and immature SEs per gram were calculated after an 8-week culture.

For PEG/maltose treatment, $0.2 \mathrm{~g}$ embryogenic tissues were transferred to each Petri plate containing maturation medium (Mat), maturation medium without PEG (No PEG), or maturation medium without maltose (No Malt). The number of mature, abnormal, and immature SEs per gram (FW) of initial embryogenic tissue were collected and calculated after 8 weeks. A normal mature SE was qualified with at least 3 well-developed cotyledons.

\subsection{Global DNA Methylation Analysis}

The global DNA methylation level was detected to measure the development condition of each treatment. Firstly, DNA was extracted from $200 \mathrm{mg}$ cultures of all SEs by using $\mathrm{CTAB}$ methods, including normal and abnormal embryos and proliferated tissues at weeks $0,1,2,3$, and 10 [29]. The DNA was then treated with RNase $(10 \mathrm{mg} / \mathrm{mL}$ ) (Solarbio Technology Co., Ltd., Beijing, China) for $60 \mathrm{~min}$ and $\mathrm{NaOH}(0.1 \mathrm{M})$ for $30 \mathrm{~min}$ to obtain RNA-free DNA samples. DNA methylation level was analyzed as the method in Gao et al. (2019) [30] with minor modification. In brief, RNA-free DNA solution (50 $\mu \mathrm{L})$ was hydrolyzed with $50 \mu \mathrm{L}$ PA (perchloric acid) and incubated at $100{ }^{\circ} \mathrm{C}$ in dry bath (Model: H2O3-PRO, Coyote Bioscience Co., Ltd., Yixing, China) for $80 \mathrm{~min}$. The hydrolyzed solution was cooled to room temperature and neutralized with $127 \mu \mathrm{L} \mathrm{KOH}(5 \mathrm{M})$ to $\mathrm{pH}$ 2.0. The supernatant was obtained after centrifugation at $12,000 \mathrm{rpm}$ and $4{ }^{\circ} \mathrm{C}$ for $10 \mathrm{~min}$. The pellets were washed with $100 \mu \mathrm{L}$ ultrapure water, and the supernatant was then separated through centrifugation. The 2 supernatants were mixed and used for Base analysis.

A total of $20 \mu \mathrm{L}$ derivatized solution was injected into a Waters E2695 HPLC instrument with a C18 column (Phenomenex 00G-4252-E0, $250 \times 4.6 \mathrm{~mm}, 5 \mu \mathrm{m}$ ). The HPLC analysis parameters were performed as oven temperature at $30{ }^{\circ} \mathrm{C}$, sample temperature at $4{ }^{\circ} \mathrm{C}$, total flow $1 \mathrm{ml}$ per minute, and wavelength $280 \mathrm{~nm}$. The gradient elution mode was adopted with mobile phase A ( $3 \% \mathrm{ACN}$ and $0.5 \% \mathrm{HAc}$ ) and mobile phase B (ultrapure water). Qualification and quantification of the bases were performed after comparing with the references. DNA methylation level was calculated according to the equation: $5 \mathrm{mC}(\%)=5 \mathrm{mC} /(5 \mathrm{mC}+\mathrm{C}) \times 100 \%$.

\subsection{RNA Extraction and Reverse Transcription}

Total RNA was extracted with a RNAprep Pure Plant Kit (Tiangen Biotech Co., Ltd., Beijing, China) as the manufacturer's instructions. Subsequently, $0.8 \mu \mathrm{g}$ of total RNA from each sample was used for cDNA synthesis using Goldenstar ${ }^{\mathrm{TM}}$ RT6 cDNA Synthesis Kit Ver.2 (Tsingke Biotech Co., Ltd., Beijing, China) according to the manufacturer's instructions. 


\subsection{Identification, Sequencing, and Phylogenetic Analyses of DNMT Genes}

To clone the DNMT genes of Pseudotsuga gaussenii, Pinus sylvestris, and Pinus taeda DNMT proteins were retrieved from NCBI (https:/ / www.ncbi.nlm.nih.gov / (accessed on 3 February 2022)) and ConGenIE (https: / / congenie.org/ (accessed on 3 February 2022)) (Supplementary Table S1) [31]. The partial coding sequences of PsCMT, PsDRM-1, PsDRM2, PSMET1-1, PsMET1-2, and PsMET1-3 genes were amplified with primers designed against the Pinus sylvestris and Picea abies gene annotation (Supplementary Table S2) using KOD-Plus-Neo DNA polymerase from TOYOBO Biotech Co., Ltd. The cloning PCR was applied as the KOD-Plus-Neo DNA polymerase manufacturer's protocol via C1000 Touch Thermal Cycler (Bio-Rad Laboratories, Inc., Hercules, CA, USA). Phylogenetic analysis for the DNMT genes was conducted using a total of 32 DNMT peptide sequences from seed plants (Table S1 from Supplementary Materials). The sequences were aligned using Clustal $\mathrm{X} 2$, and a maximum-likelihood tree with 1000 bootstrap iterations was generated using MEGA7 software [32].

\subsection{Quantitative PCR}

The qPCR amplifications were conducted with Applied Biosystems ${ }^{\mathrm{TM}}$ QuantStudio 6 Real-Time PCR System (ABI, Carlsbad, CA, USA) using Hieff UNICON ${ }^{\circledR}$ Universal Blue qPCR SYBR Green Master Mix (Yeasen Biotech Co., Ltd., Shanghai, China), $0.2 \mu \mathrm{M}$ genespecific primers (Supplementary Table S3), and $1 \mu \mathrm{L}$ cDNA (1/20 dilution). Amplification was initiated by incubation at $95^{\circ} \mathrm{C}$ for $30 \mathrm{~s}$, followed by 40 cycles of $3 \mathrm{~s}$ at $95^{\circ} \mathrm{C}$, and $20 \mathrm{~s}$ at $60{ }^{\circ} \mathrm{C}$. PCR primers were designed by primer-blast (https:/ / www.ncbi.nlm.nih.gov/tools/ primer-blast/ (accessed on 3 February 2022)) with default parameters except the product size (100-250 bp), and the primers were ordered from Beijing Tsingke Biotech Co., Ltd. Relative expression of the target genes was calculated with by the $2^{-\Delta \Delta \mathrm{Ct}}$ method by using one suitable reference gene glyceraldehyde-3-phosphate dehydrogenase (GADPH) as control [31]. The arithmetic mean of 3 biological replicates was used in data analysis.

\subsection{Statistic Analysis}

All experiments were repeated at least 3 times ( $N \geq 3$ ). Duncan's multiple range test was performed with SPSS software (IBM, Armonk, NY, USA) with the level of significance set at $p<0.05$.

\section{Results}

\subsection{Effects of MGBG in Pre-Maturation Treatment on SE Development and Maturation}

To evaluate the effect of MGBG on SE, we performed a comparison between different variants of cultivation. During MGBG treatment, the proliferation of unwanted plant tissue could be inhibited significantly (Figure 1), and the number of immature SEs decreased obviously in Figure $1 \mathrm{~b}-\mathrm{d}$. After culturing on the maturation medium for 8 weeks, the number of mature SEs (MSE), abnormal SEs (ASE), and immature SEs (ISE) were counted. As shown in Figure 2, the average number of normal mature SEs was the largest, and the average number of ASE (46 SE/g FW) and ISE (104 SE/g FW) were lower with the $50 \mu \mathrm{M}$ MGBG treatment at the pre-maturation stage. There was no significant difference in the number of MSE between MGBG treatments of $50 \mu \mathrm{M}(472 \mathrm{SE} / \mathrm{g}$ FW) and $100 \mu \mathrm{M}$ (402 SE/g FW), which were better than the control of $0 \mu \mathrm{M} \mathrm{MGBG}$ (330 SE/g FW) and the $200 \mu \mathrm{M}(326 \mathrm{SE} / \mathrm{g}$ FW) MGBG treatment.

\subsection{The Development of Pseudotsuga gaussenii SEs without PEG or Maltose}

In order to study the effects of polyethylene glycol (PEG) or maltose on SE development, the complete maturation medium (Mat), PEG free medium (no PEG), and maltose free medium (no Malt) were used for culturing Pseudotsuga gaussenii SEs. In the first three weeks of maturation, there were obviously visible SEs on all mature media (Figure $3 b, e, h)$. However, in the later developmental stages, the embryogenic tissue cultured on PEG-free medium was over-proliferated, and the embryo structure was gradually 
degraded (Figure 3i). There was no obvious SE in the maturation culture at the 10th week (Figure 3i). On the contrary, plant tissue proliferation on maltose free medium was the lowest (Figure 4a). Although the total number of SEs was not increased significantly with no Malt treatment, the number of MSE increased obviously from $287 \mathrm{SE} / \mathrm{g}$ FW (Mat) to 399 SE/g FW (no Malt); the number of ASE decreased from 111 SE/g FW (Mat) to 43 SE/g FW (no Malt), and the number of ISE almost reduced to a half (Figure $4 \mathrm{~b}$ ). These results suggested that PEG was an important supplement of the mature medium and the lower sugar source by elimination of maltose from the mature medium was better for SE maturation.
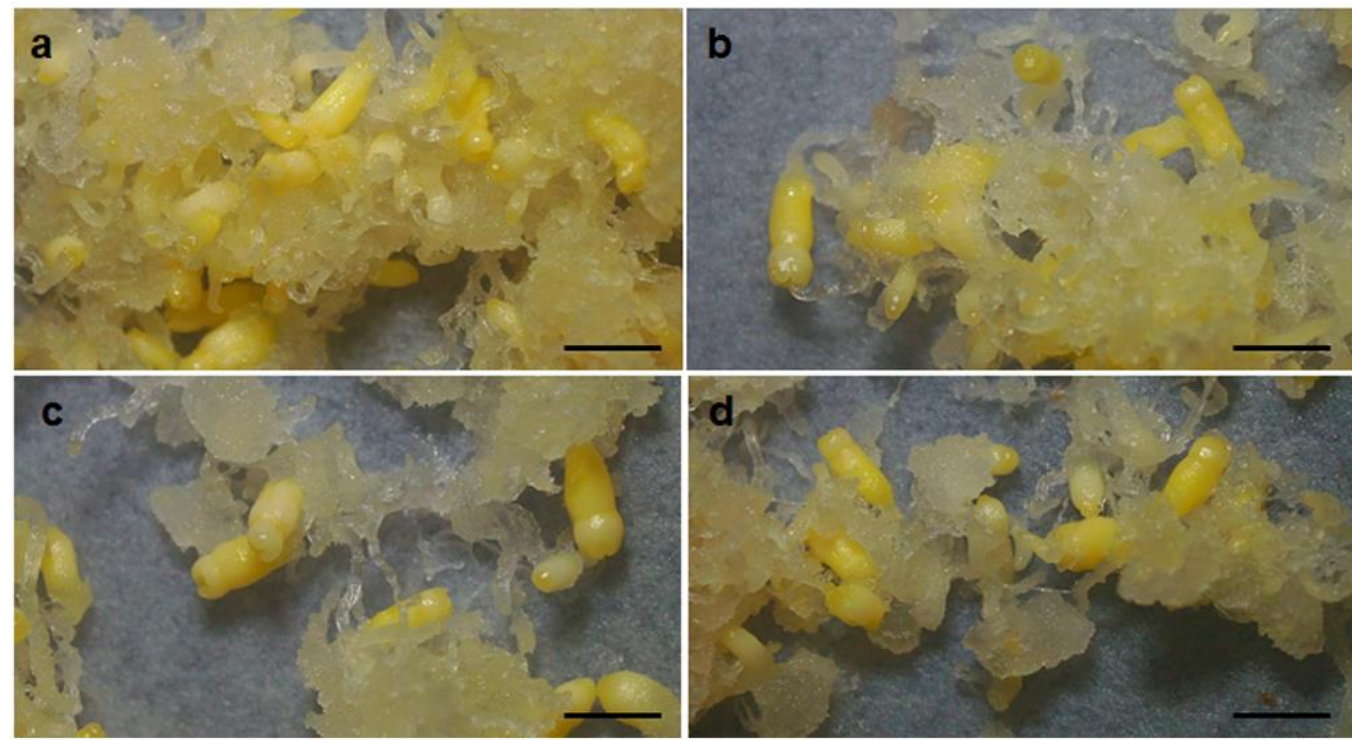

Figure 1. SE maturation cultures at week 8 after the pre-maturation treatments using at different concentrations in Pseudotsuga gaussenii. (a) No MGBG treatment. (b) $50 \mu \mathrm{M}$ MGBG treatment. (c) $100 \mu \mathrm{M}$ MGBG treatment. (d) $200 \mu \mathrm{M}$ MGBG treatment. All bars $=2000 \mu \mathrm{m}$.



Figure 2. The number of SEs after an 8-week maturation culture in Pseudotsuga gaussenii. The cultures were treated with $0,50,100$, or $200 \mu \mathrm{M}$ MGBG, respectively, in the pre-maturation treatment. MSE represents mature SEs; ASE represents abnormal SEs; ISE represents immature SEs; ALL represents all SEs. Different letters indicate the significant difference at $p<0.05$ among different mature cultivation. Mean $\pm \mathrm{SD}, n \geq 3$. 

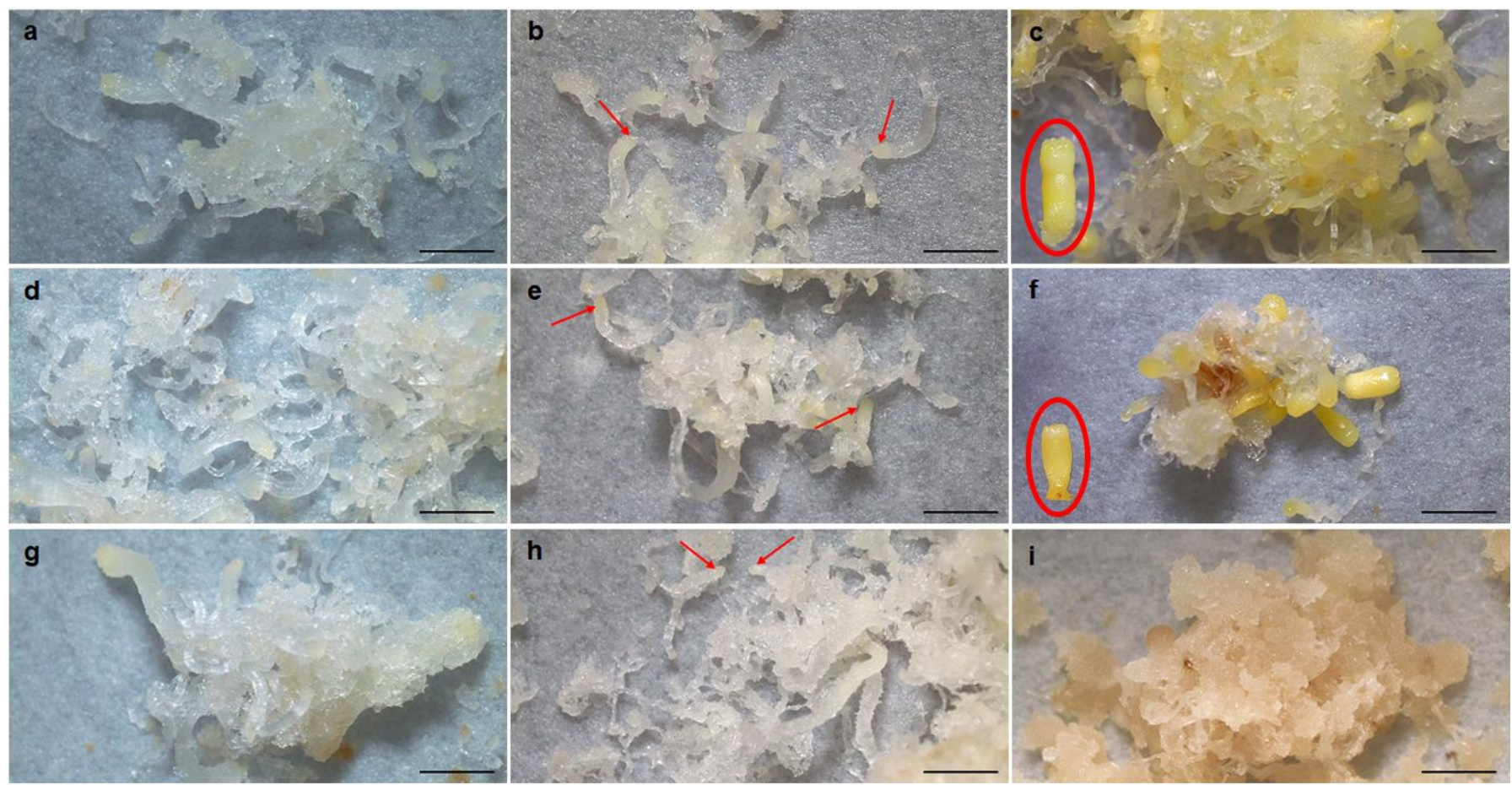

Figure 3. The SE cultures of Pseudotsuga gaussenii at the 1 st week $(\mathbf{a}, \mathbf{d}, \mathbf{g}), 3$ rd week $(\mathbf{b}, \mathbf{e}, \mathbf{h})$ and 10th week (c,f,i) with the complete mature media (Mat, a-c), maltose free medium (No Malt, $\mathbf{d}-\mathbf{f}$ ), and PEG free medium (No PEG, $\mathbf{g}-\mathbf{i}$ ). The red arrows represent early somatic embryos. The inserted in $(\mathbf{c}, \mathbf{f})$ show mature SEs with developed cotyledons. All bars $=2000 \mu \mathrm{m}$.
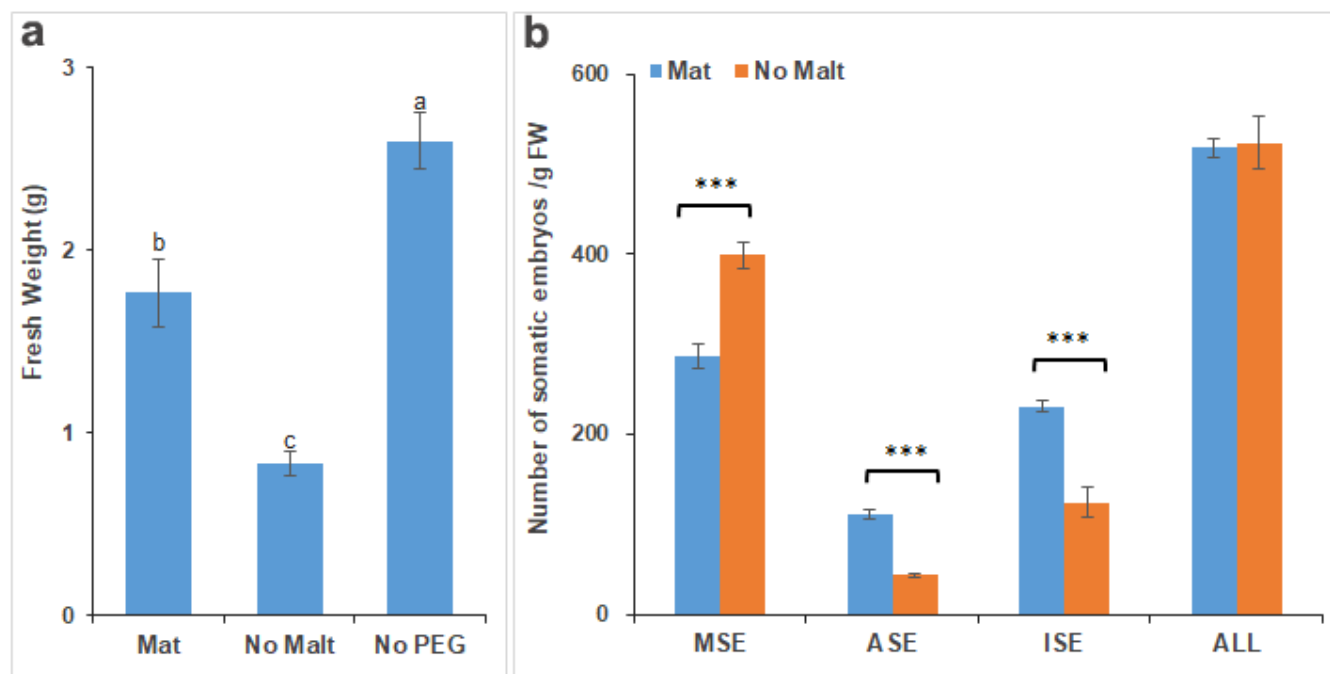

Figure 4. Effects of maltose and/or PEG on the SE cultures of Pseudotsuga gaussenii. Results of tissue weight (a) and SE members (b) were obtained with the treatments using mature media (Mat), maltose free medium (No Malt) and PEG free medium (No PEG). MSE represents mature SEs; ASE represents abnormal SEs; ISE represents immature SEs; ALL represents the total of SEs. Different letters indicate the significant difference at $p<0.05$ among different mature cultivation, and the stars indicate the significant difference at $p<0.01$. Mean $\pm \mathrm{SD}, n \geq 3$.

\subsection{Effects of PEG or Maltose on DNA Methylation of SE Cultures}

DNA methylation levels of the SE cultures under different treatments were detected to study their influence on SE development at a molecular level. It can be seen from Figure 5 that the total DNA methylation level of SE cultures using the complete mature medium and maltose free medium gradually increased, while the DNA methylation level significantly 
decreased at the 10 th week $(10.35 \%)$ and was lower than that at the first week $(12.56 \%)$ in the culture with PEG free medium. Besides, the DNA methylation level of SE cultures with maltose free medium $(20.28 \%)$ was significantly higher than others at the 10 th week. This phenomenon is also consistent with the number of mature SEs developed with the different treatments in Pseudotsuga gaussenii.

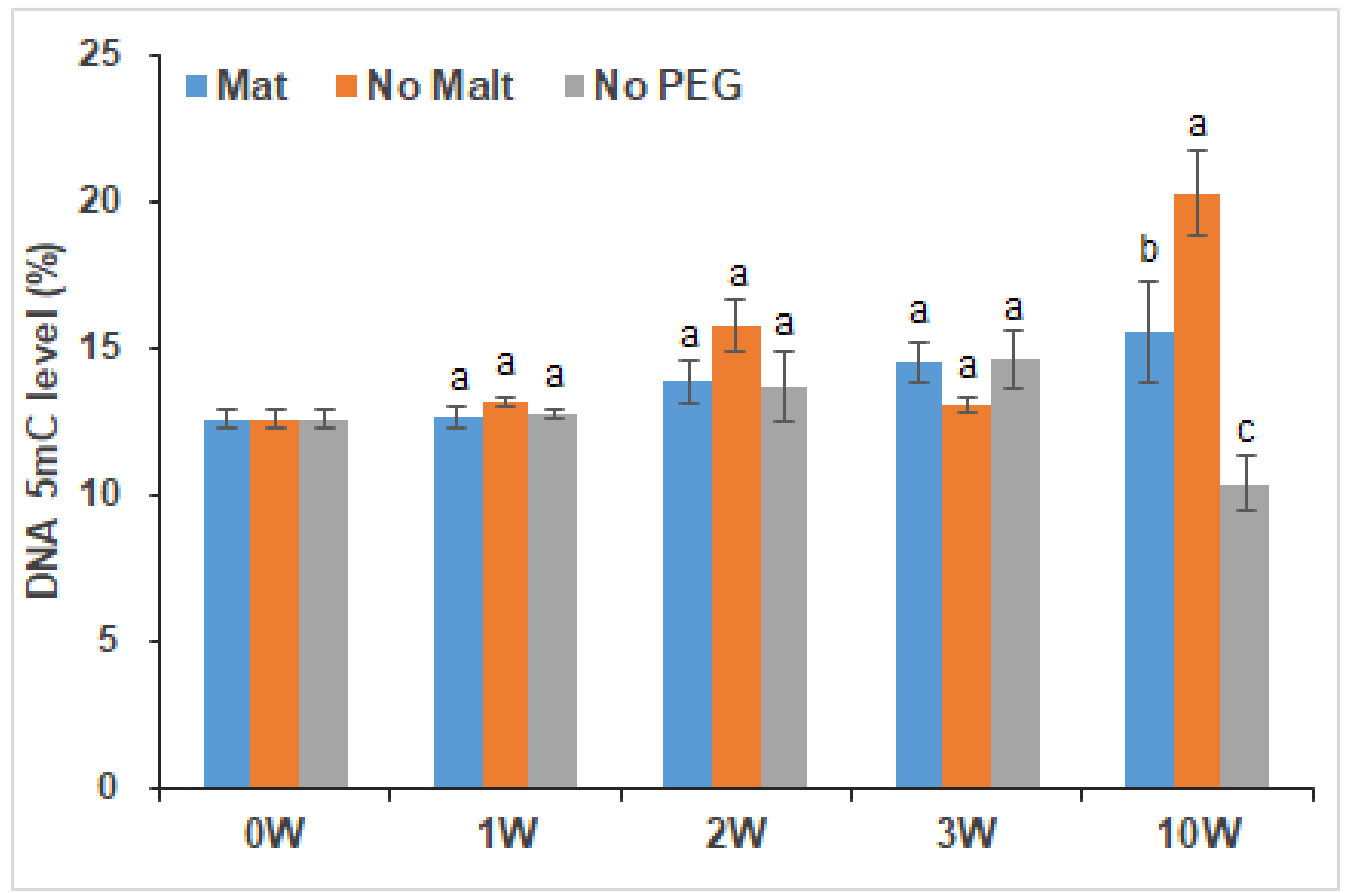

Figure 5. The DNA methylation levels of SE cultures at week 0, 1, 2, 3, and 10 with the complete mature medium (Mat), maltose free medium (No Malt), and PEG free medium (No PEG). Different letters indicate the significant difference at $p<0.05$ among different mature cultivations. Mean $\pm \mathrm{SD}$, $n \geq 3$.

Meanwhile, the partial DNA methyltransferase genes MET1-1 (Methyltransferase 1-1), MET1-2 (Methyltransferase 1-2), MET1-3 (Methyltransferase 1-3), CMT3 (Chromethylase 3), DRM1 (Domains rearranged methylase 1-2), and DRM2 (Domains rearranged methylase 2) were cloned to detect the expression of DNA methyltransferase genes in the process of SE development (Figure 6). As it can be seen from Figure 7, except MET1-3, the expression of DNA methyltransferase genes was obviously higher when PEG free medium was used than that using either the maturation medium or maltose free medium at the 1st, 3rd, and 10th weeks; the expression level of DNA methyltransferase genes in SE tissue in maltose free medium was higher than with complete maturation culture at the third week. In addition, it can be seen from Figure 7 that the expression of CMT, MET1-1, and MET1-3 decreased after one week of maturation, while the gene expression of MET1-2 largely increased. The expression of DRM1 and DRM2 did not change significantly, which suggested the expression level of DNA methyltransferase genes was different at different stages of SE development. On the other hand, different DNA methyltransferase genes plays an important role in different tissues and at different development stages [33-36]. 


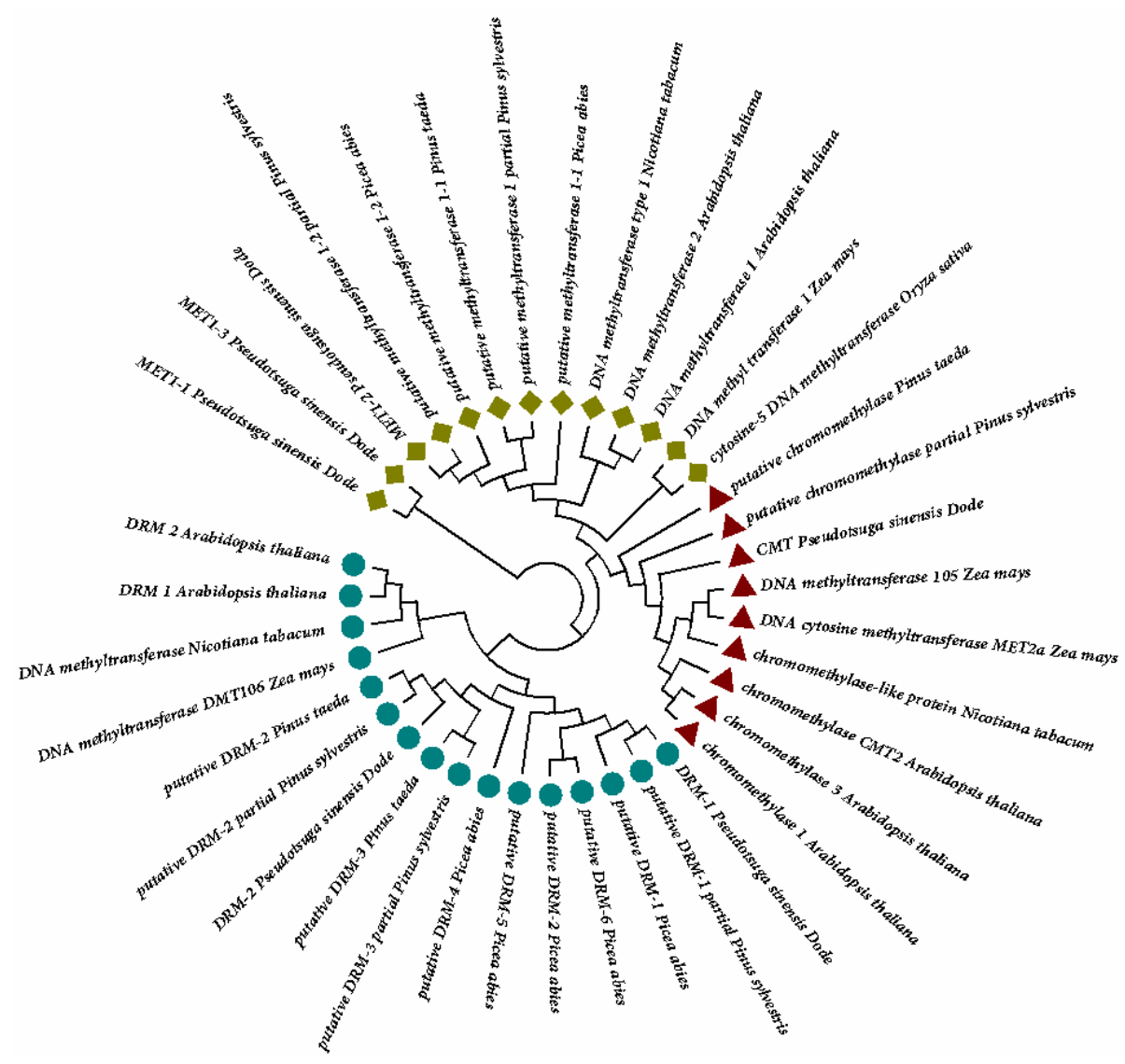

Figure 6. Phylogenetic analysis of DNMTs in seed plants. In the phylogenetic tree, DNMT sequences formed three main branches: methyltransferase 1 (MET1, green diamond), chromomethylase (CMT, red triangle) and domains rearranged methyltransferase (DRM, blue circle). The MET1 and CMT families were more closely related. The DRM and CMT families formed two subclades, one for angiosperms and one for gymnosperms.
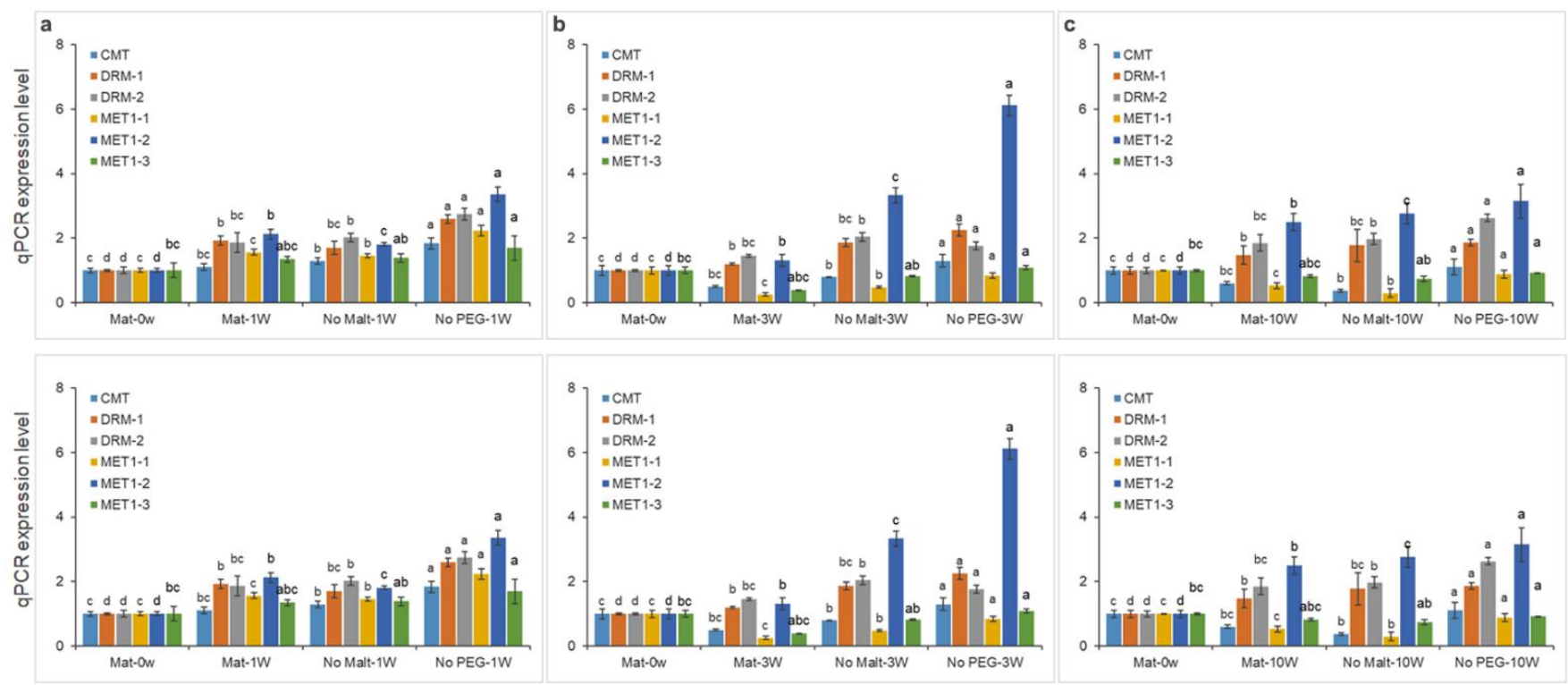

Figure 7. The qPCR results of DNMTs in the SE cultures with different treatments showing DNMTs at the 1st week (a), the 3rd week (b), and the 10th week (c) with the complete mature media (Mat), maltose free medium (No Malt) and PEG free medium (No PEG). Different letters indicate the significant difference at $p<0.05$ among different mature cultivations. Mean $\pm \mathrm{SD}, n \geq 3$. 


\section{Discussion}

\subsection{The Importance of Application Time and Concentrations of MGBG}

Over-proliferation often occurs at the SE maturation stage of Pseudotsuga gaussenii, which is a serious problem to be solved. In Picea glauca (Moench) Voss [9], MGBG supplement in maturation medium could either promote or inhibit embryo development depending on how it was applied to the cultures. In our laboratory, previous studies suggested that MGBG application at the SE maturation stage had no obvious effect on SE development in Pseudotsuga gaussenii. However, it was conducive for suppressing the over-proliferation of embryogenic tissue when MGBG was used in the pre-maturation treatment. This might be due to the cause that MGBG of the pre-treatment in the liquid medium could easily access the cells of embryogenic tissues, and thus, the functions of MGBG were enhanced. Since part of the SEs was inhibited for further development at the early stage, the over-proliferation of tissue was reduced in SE maturation culture, resulting in better SE development and maturation.

Besides application time, concentrations of MGBG are also important. With prematuration treatments of $50 \mu \mathrm{M}$ or $100 \mu \mathrm{M}$ MGBG in this study, the over-proliferation of embryogenic tissues was inhibited efficiently, and the number of MSE increased significantly without affecting the total SE number. Additionally, $400 \mu \mathrm{M}$ MGBG maturation treatment could inhibit SE development in white spruce, and the SE development was restarted with the $800 \mu \mathrm{M}$ MGBG maturation treatment [9]. Previous studies showed that the application of MGBG could cause a significant decrease of both spermidine and spermine during conifer SEis [7,9], resulting in the reduced proliferation embryogenic tissue and thus more nutrients available for SE development. These facts prove that MGBG could reduce the over-proliferation of embryogenic tissues and promote SE development in Pseudotsuga gaussenii when it is applied at the right time with suitable concentrations.

\subsection{The Correlation between DNA Methylation of SEs and PEG/Maltose Treatments}

PEG/maltose has been illustrated for influencing osmotic pressure in maturation cultures [37-39]. In Carica papaya L., 6\% PEG treatment increased endogenous sucrose and starch in plant tissue, which were the key energy for SE development [39]. In Abies nordmanniana, maltose was better for SE development than sucrose [40]. All of these indicate that PEG/maltose could promote SE morphogenesis and development, resulting in more MSE. In this study, PEG and maltose changed DNA methylation levels remarkably and influenced SE morphogenesis significantly in Pseudotsuga gaussenii. The DNA methylation level increased slightly due to the development of SEs during the maturation stage in Mat and no Malt, while the degraded SEs resulted in the decrease of DNA methylation at 10th week in no PEG.

In the maturation medium without PEG, SEs could not develop normally, resulting in heavily proliferated plant tissue. Meanwhile, the expression levels of DNA methyltransferase increased significantly. Obviously, this phenomenon was contrary to normal cell development but similarly to a tumor, which has global genomic hypomethylation and aberrant hypermethylation of tumor suppressor genes (TSGs) [41,42]. Overexpression of DNMTs in tumors can drive de novo methylation of CpG island sites, leading to TSGs inactivation mediated by methylation of CpG sites, thus promoting the further development of tumors and causing genome-wide DNA hypomethylation [43,44]. Thus, we speculated that during the first and third weeks of SE maturation, due to the lack of PEG, the expression of DNA methyltransferase genes sharply increased, especially MET1-2, causing de novo methylation of $\mathrm{CpG}$ island site of genes similar as TSGs, which eventually led to the malignant proliferation and global genomic hypomethylation.

On the contrary to the result using PEG free maturation medium, although elimination of maltose from the culture medium resulted in a decreased carbon source, the SE development could be completed, accompanied by hypermethylation, which indicated that the total DNA methylation level was related to SE development [31,45]. In addition, compared with the complete mature medium, the expression of DNA methyltransferase 
genes increased in SE cultures in maltose-free medium at the third week, and the level of global DNA methylation increased during the later SE developmental stages. It was similar to the phenomenon after suffering from abiotic stress such as drought and salinity [46-48]. The reduced sugar source could reduce the energy source for tissue growth, resulting in the slightly enhanced expression of DNA methyltransferase genes and the increase of global DNA methylation level at the latter embryo developmental stages, which is more conducive to the development of SEs.

\section{Conclusions}

In summary, the supplement of MGBG at low concentrations in the pre-maturation treatment could inhibit or reduce the over-proliferation of embryogenic tissue and benefit SE development in the maturation cultures in Pseudotsuga gaussenii. In addition, PEG 4000 plays a key role in stimulating SE development and maturation. Maturation cultures supplemented with a lower carbon source, or less sugar, resulted in more fully developed SEs. During PEG/maltose treatment, DNA methylation levels were changing in the cultures with the SE developmental stages and the culture conditions. This is the first report on SEis in Pseudotsuga gaussenii. Analysis of DNA methyltransferase genes and DNA methylation levels during SE maturation in this research could further our knowledge about the functions of PEG and/or maltose on SE development and maturation in conifers.

Supplementary Materials: The following are available online at https:/ / www.mdpi.com/article/ 10.3390/f13020288/s1, Table S1: sequences used in the identification and phylogenetic analysis of DNMTs. Table S2: primers for Sanger sequencing of Pseudotsuga gaussenii DNMT genes. Table S3: qPCR primers for Pseudotsuga gaussenii DNMT genes.

Author Contributions: Y.G. contributed to the manuscript writing. Conceived and designed the experiments: J.Z. (Jinfeng Zhang), L.K. and Y.G. Performed the experiments: Y.G., J.Z. (Jinfeng Zhang), X.C., Y.C., H.Z., R.Z. and C.L. Analyzed the data: Y.G. Contributed reagents/materials/analysis tools: Y.G. Writing—original draft preparation: Y.G. Writing—review and editing: L.K. and J.Z. (Jian Zhao). All authors have read and agreed to the published version of the manuscript.

Funding: This paper was funded by State Key Laboratory of Tree Genetics and Breeding (K2018202), National Key R\&D Program of China (2017YDF0600404-1), the project fund (Somatic embryogenesis and high efficient propagation technology in trees) provided by Beijing Advanced Innovation Center for Tree Breeding by Molecular Design, the National Natural Science Foundation of China (31901289), Key R\&D Program of Hebei Province, China (20326333D), Major Science and Technology Special Project of Xuchang, Henan province, China (20170112006).

Data Availability Statement: The datasets generated and/or analyzed during the current study are available from the corresponding author on reasonable request.

Acknowledgments: We would like to show our special thanks to Shen Zhou Lv Peng Agricultural Technology Co., Ltd. for all the related supports.

Conflicts of Interest: The authors declare no conflict of interest.

\section{References}

1. Quiroz-Figueroa, F.R.; Rojas-Herrera, R.; Galaz-Avalos, R.M.; Loyola-Vargas, V.M. Embryo production through somatic embryogenesis can be used to study cell differentiation in plants. Plant Cell Tissue Organ Cult. 2006, 86, 285-301. [CrossRef]

2. Klimaszewska, K.; Hargreaves, C.; Lelu-Walter, M.A.; Trontin, J.F. Advances in conifer somatic embryogenesis since year 2000. In In Vitro Embryogenesis in Higher Plants; Germana, M.A., Lambardi, M., Eds.; Humana Press: New York, NY, USA, 2016; Volume 1375, pp. 131-166.

3. Thorpe, T.A.; Yeung, E.C.; Pullman, G.S.; Bucalo, K. Pine somatic embryogenesis using zygotic embryos as explants. In Plant Embryo Culture; Thorpe, T., Yeung, E., Eds.; Methods in Molecular Biology (Methods and Protocols); Humana Press: New York, NY, USA, 2011; Volume 710, pp. 267-291.

4. Tereso, S.; Zoglauer, K.; Milhinhos, A.; Miguel, C.; Oliveira, M.M. Zygotic and somatic embryo morphogenesis in Pinus pinaster: Comparative histological and histochemical study. Tree Physiol. 2007, 27, 661-669. [CrossRef] [PubMed] 
5. Negro, A.; Méndez, R.; Martin-villacorta, J.; Ortiz, A.I.; Ordóñez, D. A simplified method for the determination of methylglyoxal bis(guanylhydrazone), MGBG, in biological fluids by reversed-phase ion-pair HPLC. J. Liq. Chromatogr. 1991, 14, $2409-2418$. [CrossRef]

6. Niemi, K.; Sarjala, T.; Chen, X.; Häggman, H. Spermidine and methylglyoxal bis(guanylhydrazone) affect maturation and endogenous polyamine content of Scots pine embryogenic cultures. J. Plant Physiol. 2002, 159, 1155-1158. [CrossRef]

7. El Meskaoui, A.; Trembaly, F.M. Effects of exogenous polyamines and inhibitors of polyamine biosynthesis on endogenous free polyamine contents and the maturation of white spruce somatic embryos. Afr. J. Biotechnol. 2009, 8, 6807-6816.

8. Li, X.Y.; Huang, F.H.; Gbur, E.E. Polyethylene glycol-promoted development of somatic embryos in loblolly pine (Pinus taeda L.). In Vitro Cell. Dev. Biol.-Plant 1997, 33, 184-189. [CrossRef]

9. Kong, L.; Attree, S.M.; Fowke, L.C. Effects of polyethylene glycol and methylglyoxal bis (guanylhydrazone) on endogenous polyamine levels and somatic embryo maturation in white spruce (Picea glauca). Plant Sci. 1998, 133, 211-220. [CrossRef]

10. Ramarosandratana, A.; Harvengt, L.; Bouvet, A.; Calvayrac, R.; Pâques, M. Effects of carbohydrate source, polyethylene glycol and gellan gum concentration on embryonal-suspensor mass (ESM) proliferation and maturation of maritime pine somatic embryos. In Vitro Cell. Dev. Biol.-Plant 2001, 37, 29-34. [CrossRef]

11. Salaj, T.; Matusikova, I.; Fraterova, L.; Pirselova, B.; Salaj, J. Regrowth of embryogenic tissues of Pinus nigra following cryopreservation. Plant Cell Tissue Organ Cult. 2011, 106, 55-61. [CrossRef]

12. Wu, C.T.; Morris, J.R. Genes, genetics, and epigenetics: A correspondence. Science 2001, 293, 1103-1105. [CrossRef]

13. Zhang, H.M.; Lang, Z.B.; Zhu, J.K. Dynamics and function of DNA methylation in plants. Nat. Rev. Mol. Cell Biol. 2018, 19, 489-506. [CrossRef] [PubMed]

14. Hu, G.; Xu, Q. Mechanism of de novo DNA methylation in plants. Chin. Sci. Bull. 2021, 66, 1821-1834. [CrossRef]

15. Chan, S.W.L.; Henderson, I.R.; Jacobsen, S.E. Gardening the genome: DNA methylation in Arabidopsis thaliana. Nat. Rev. Genet. 2005, 6, 351-360. [CrossRef]

16. Stroud, H.; Do, T.; Du, J.M.; Zhong, X.H.; Feng, S.H.; Johnson, L.; Patel, D.J.; Jacobsen, S.E. Non-CG methylation patterns shape the epigenetic landscape in Arabidopsis. Nat. Struct. Mol. Biol. 2014, 21, 64-72. [CrossRef]

17. Razin, A.; Cedar, H. DNA methylation and gene expression. Microbiol. Res. 1991, 55, 451-458. [CrossRef]

18. Mei, X.; Li, P.; Wang, L.; Liu, C.; Zhou, L.; Li, C.; Cai, Y. Imprinting, methylation, and expression characterization of the maize ETHYLENE-INSENSITIVE 2-like gene. Crop J. 2019, 7, 49-57. [CrossRef]

19. Yaari, R.; Katz, A.; Domb, K.; Harris, K.D.; Zemach, A.; Ohad, N. RdDM-independent de novo and heterochromatin DNA methylation by plant CMT and DNMT3 orthologs. Nat. Commun. 2019, 10, 1613. [CrossRef]

20. Lewis, J.; Bird, A. DNA methylation and chromatin structure. FEBS Lett. 1991, 285, 155-159. [CrossRef]

21. Law, J.A.; Jacobsen, S.E. Establishing, maintaining and modifying DNA methylation patterns in plants and animals. Nat. Rev. Genet. 2010, 11, 204-220. [CrossRef]

22. Razin, A.; Cedar, H. DNA methylation and genomic imprinting. Cell 1994, 77, 473-476. [CrossRef]

23. Heringer, A.S.; Steinmacher, D.A.; Fraga, H.P.F.; Vieira, L.N.; Ree, J.F.; Guerra, M.P. Global DNA methylation profiles of somatic embryos of peach palm (Bactris gasipaes Kunth) are influenced by cryoprotectants and droplet-vitrification cryopreservation. Plant Cell Tissue Organ Cult. 2013, 114, 365-372. [CrossRef]

24. Ahmadi, B.; Ahmadi, M.; Teixeira da Silva, J.A. Microspore embryogenesis in Brassica: Calcium signaling, epigenetic modification, and programmed cell death. Planta 2018, 248, 1339-1350. [CrossRef] [PubMed]

25. Xing, M.Q.; Zhang, Y.J.; Zhou, S.R.; Hu, W.Y.; Wu, X.T.; Ye, Y.J.; Wu, X.X.; Xiao, Y.P.; Li, X.; Xue, H.W. Global analysis reveals the crucial roles of DNA methylation during rice seed development. Plant Physiol. 2015, 168, 1417-1554. [CrossRef] [PubMed]

26. Kong, L.; von Aderkas, P. A novel method of cryopreservation without a cryoprotectant for immature somatic embryos of conifer. Plant Cell Tissue Organ Cult. 2011, 106, 115-125. [CrossRef]

27. Litvay, J.D.; Verma, D.C.; Johnson, M.A. Influence of a loblolly pine (Pinus taeda L.). Culture medium and its components on growth and somatic embryogenesis of the wild carrot (Daucus carota L.). Plant Cell Rep. 1985, 4, 325-328. [CrossRef]

28. Kong, L.; von Aderkas, P. Genotype effects on ABA consumption and somatic embryo maturation in interior spruce (Picea glauca $\times$ engelmanni). J. Exp. Bot. 2007, 58, 1525-1531. [CrossRef]

29. Borges, A.; Rosa, M.S.; Recchia, G.H.; de Queiroz-Silva, J.R.; Bressan, E.D.; Veasey, E.A. CTAB methods for DNA extraction of sweetpotato for microsatellite analysis. Sci. Agric. 2009, 66, 529-534. [CrossRef]

30. Gao, Y.; Hao, J.L.; Wang, Z.; Song, K.J.; Ye, J.H.; Zheng, X.Q.; Liang, Y.R.; Lu, J.L. DNA methylation levels in different tissues in tea plant via an optimized HPLC method. Hortic. Environ. Biotechnol. 2019, 60, 967-974. [CrossRef]

31. Alakarppa, E.; Salo, H.M.; Valledor, L.; Canal, M.J.; Haggman, H.; Vuosku, J. Natural variation of DNA methylation and gene expression may determine local adaptations of Scots pine populations. J. Exp. Bot. 2018, 69, 5293-5305. [CrossRef]

32. Kumar, S.; Stecher, G.; Tamura, K. MEGA7: Molecular evolutionary genetics analysis version 7.0 for bigger datasets. Mol. Biol. Evol. 2016, 33, 1870-1874. [CrossRef]

33. Kawakatsu, T.; Nery, J.R.; Castanon, R.; Ecker, J.R. Dynamic DNA methylation reconfiguration during seed development and germination. Genome Biol. 2017, 18, 171. [CrossRef] [PubMed]

34. Fujimoto, R.; Sasaki, T.; Nishio, T. Characterization of DNA methyltransferase genes in Brassica rapa. Genes Genet. Syst. 2006, 81, 235-242. [CrossRef] [PubMed] 
35. Chakraborty, T.; Kendall, T.; Grover, J.W.; Mosher, R.A. Embryo CHH hypermethylation is mediated by RdDM and is autonomously directed in Brassica rapa. Genome Biol. 2021, 22, 140. [CrossRef] [PubMed]

36. Pandey, P.; Malik, A.A.; Kumar, K.; Negi, M.S.; Tripathi, S.B. Changes in DNA methylation levels during seed development in Jatropha curcas. J. Genet. 2016, 95, 13-18. [CrossRef] [PubMed]

37. Shoji, M.; Sato, H.; Nakagawa, R.; Funada, R.; Kubo, T.; Ogita, S. Influence of osmotic pressure on somatic embryo maturation in Pinus densiflora. J. For. Res. 2006, 11, 449-453. [CrossRef]

38. Rai, M.K.; Jaiswal, V.S.; Jaiswal, U. Effect of selected amino acids and polyethylene glycol on maturation and germination of somatic embryos of guava (Psidium guajava L.). Sci. Hortic. 2009, 121, 233-236. [CrossRef]

39. Vale, E.M.; Reis, R.S.; Passamani, L.Z.; Santa-Catarina, C.; Silveira, V. Morphological analyses and variation in carbohydrate content during the maturation of somatic embryos of Carica papaya. Physiol. Mol. Biol. Plants 2018, 24, 295-305. [CrossRef]

40. Norgaard, J.V. Somatic embryo maturation and plant regeneration in Abies nordmanniana Lk. Plant Sci. 1997, 124, $211-221$. [CrossRef]

41. Vertino, P.M.; Yen, R.W.; Gao, J.; Baylin, S.B. De novo methylation of CpG island sequences in human fibroblasts overexpressing DNA (cytosine-5-)-methyltransferase. Mol. Cell Biol. 1996, 16, 4555-4565. [CrossRef]

42. Daniel, F.I.; Cherubini, K.; Yurgel, L.S.; de Figueiredo, M.A.; Salum, F.G. The role of epigenetic transcription repression and DNA methyltransferases in cancer. Cancer 2011, 117, 677-687. [CrossRef]

43. He, M.; Fan, J.; Jiang, R.; Tang, W.X.; Wang, Z.W. Expression of DNMTs and genomic DNA methylation in gastric signet ring cell carcinoma. Mol. Med. Rep. 2013, 8, 942-948. [CrossRef]

44. Nishiyama, A.; Nakanishi, M. Navigating the DNA methylation landscape of cancer. Trends Genet. 2021, 11, 1012-1027. [CrossRef]

45. Kumar, S.; Mohapatra, T. Dynamics of DNA methylation and its functions in plant growth and development. Front. Plant Sci. 2021, 12, 858. [CrossRef]

46. Falahi, A.; Zarei, L.; Cheghamirza, K. Most drought-induced DNA methylation changes switched to pre-stress state after re-irrigation in barley (Hordeum vulgare L.) cultivars. Cereal Res. Commun. 2021, 3, 1-10. [CrossRef]

47. Lan, Z.; Xu, Y.H.; Wang, J.B. DNA-methylation changes induced by salt stress in wheat Triticum aestivum. Afr. J. Biotechnol. 2009, 8, 6201-6207. [CrossRef]

48. Joel, G.A.J. Epigenetic responses to drought stress in rice (Oryza sativa L.). Physiol. Mol. Biol. Plants 2013, $19,379-387$. 